\title{
Status vitamin D in Ukraine patients with Grave's Disease
}

\author{
Victor Kravchenko*, Oleg Rakov and Elen Kovzun \\ Department of epidemiology endocrine diseases, Institute of Endocrinology and Metabolism. VP Komissarenko National Academy of Medical Sciences of
} Ukraine, Ukraine

Submission: February 02, 2021; Published: March 17, 2021

*Corresponding author: Victor Kravchenko, Department of epidemiology endocrine diseases, Institute of Endocrinology and Metabolism. VP Komissarenko National Academy of Medical Sciences of Ukraine, 4114, street Vyshgorodskaya, 69, Ukraine

\begin{abstract}
Background: Vitamin D, immunological parameters, and thyroid function.

Objective: Study the effect of vitamin D on immunological parameters and thyroid function.

Patients and Methods: The open-label controlled study included 102 patients with moderate Grave's disease (GD) who applied to the consulting clinic of the Institute of Endocrinology and Metabolism. VP Komissarenko NAMS of Ukraine "in the period 2018-2020. The control group included 42 people without thyroid pathology. immunochemiluminescent determination of 25(OH)D, antibodies to receptor TSH and TPO, radioimmune determination of thyroid hormones, ultrasound examination of the thyroid gland.
\end{abstract}

Results: The level of vitamin D, determined by metabolite $25(\mathrm{OH}) \mathrm{D}$, in the serum of patients was significantly reduced compared to control. With age, vitamin D deficiency increased. At the age of 19-29.9 years the median was 59.1, at the age 30-49.9-47.0, at the age 50-65 years $26,1 \mathrm{nmol} / \mathrm{l}$. At the same time, an increase in the content of antibodies to thyroid-stimulating hormone in the blood serum was found. During treatment with tyrosol, along with a decrease in thyroid function, a decrease in the level of TSH Ab was observed. Complex treatment with tyrosol and vitamin D contributed to an even greater decrease in the level of TSH Ab. There was increase in TSH levels after 3 months. and a significant reduction volume thyroid after 6 months treatment.

Conclusion: The use of vitamin D in the treatment of GD with tyrosol for 3-6 months reduces the level of TSH Ab, volume thyroid and increases the level of TSH.

Keywords: Thyroid; Grave's disease; Vitamin D; 25(OH)D; TSH Ab; ATPO; TSH; fT4; fT3

\section{Introduction}

Vitamin D exists in the form of vitamin D2 (ergocalciferol) and D3 (cholecalciferol), after passing through the liver form the metabolite 25 hydroxy calciferol $(25-(\mathrm{OH}) \mathrm{D})$, which circulates in the blood and is the main indicator of this vitamin [1,2]. Concentrations of 25- $(\mathrm{OH})$ D in the body are under genetic control, using single nucleotide polymorphisms (SNRs) around genes involved in the synthesis, metabolism, and transport of vitamin D $[3,4]$. Vitamin due to the presence of the receptor (VDR), which is found in almost all nuclear cells is an important regulator in the pathogenesis of many diseases. There are increasing reports that the metabolic enzymes VDR and vitamin D are involved in various parts of innate and adaptive immunity, which is of great clinical importance $[5,6]$. Consideration of scientific research over the past 20 years regarding the role of cellular and humoral immunity in the occurrence of autoimmune thyroid diseases shows their important participation in adaptive and innate immunity [7].

The most common of these are autoimmune thyroiditis (Hashimoto's disease) and autoimmune thyrotoxicosis (GD). The prevalence of hyperthyroidism is $1.2-1.6 \%$ of them $0.5-0.6$ overt and $0.7-1 \%$ subclinical [8]. The most common cause of this disease is GD. Organ-specific autoimmune disease, the main manifestation of which is the formation of circulating autoantibodies to the thyroid-stimulating hormone receptor. Binding of autoantibodies to the receptor causes the release of thyroid hormones and thyrocyte hyperplasia, the clinic of thyrotoxicosis. The value of vitamin D in the pathogenesis of GD has been the subject of research in recent years in various countries [9-12]. The presence of vitamin D deficiency in patients with GD has been established. 
The question of the causal relationship between vitamin D deficiency and GD and the importance of this vitamin for thyroid function in the treatment of GD deserves special attention $[12,13]$. The aim of the study was to investigate the level of 25- $(\mathrm{OH}) \mathrm{D}$ in the body in patients with GD and its relationship with thyroid function.

\section{Methods}

\section{Setting}

The open-label controlled study included 102 patients with moderate GD who applied to the consulting clinic of the Institute of Endocrinology and Metabolism. VP Komissarenko NAMS of Ukraine "in the period 2018-2020. The control group included 42 people without thyroid pathology. Written informed consent was taken from all patients to participate in this study, and the ethical committee of the Institute of Endocrinology and Metabolism VP Komissarenko National Academy of Medical Sciences of Ukraine approved the study.

\section{Inclusion Criteria}

Patients with GD were verified according to international diagnostic standards, the study included patients able to comply with the study protocol.

\section{Exclusion Criteria}

Age of patients less than 19 years and older than 65; severe dysfunction of internal organs, kidneys and liver; disorders of the hematopoietic system; pregnancy; patients taking other antithyroid drugs for previously diagnosed severe and mild HG; patients with the presence of nodules of the thyroid gland; patients with moderate and severe orbitopathy; patients taking drugs that contain vitamin D and mineral supplements with selenium; chemotherapy or radiotherapy for malignant tumors the previous 5 months; patient incompatibility. Patients were divided into two groups depending on the therapy. The first group included 52 subjects who received tyrosol in an initial dose of 20 $30 \mathrm{mg}$ per day with a subsequent transition to maintenance doses of 5-10 mg per day as the disease is compensated. The second group consisted of 52 patients. They took tyrosol at a dose of 20$30 \mathrm{mg}$ per day and vitamin D 2000 IU per day.

\section{Instrumental Tests}

Ultrasound examinations of the thyroid gland were performed with the device "Toshiba" SSA-580A and "Ultima" RA GRIS.941217.01343. The size of the thyroid gland was determined according to the recommendations of Brunn [14]. Ultrasound examination was performed before treatment and 3 and 6 months after treatment.

\section{Biochemical Tests}

Normal values for fT4 were 11.5-23.0 pmol / l and fT3 2.5-
$5.8 \mathrm{pmol} / \mathrm{l}$, reference values of TSH were in the range of 0.17 $4.05 \mathrm{mIU} / \mathrm{ml}$. When determining the level of TSH Ab in the serum used an automatic immunochemiluminescent system IMMULITE 2000 which uses recombinant human TSH receptors (hTSHR). Due to the determination of stimulating autoimmune antibodies, the differential diagnosis of GD is reliable (sensitivity 98.3\%, specificity $99.7 \%$ ). Normal values of TSH Ab were considered to be not exceeding $0.5 \mathrm{mOd} / \mathrm{l}$. The norm was the concentration of antibodies from 0 to $35 \mathrm{IU} /$ liter.

Determination of the level of 25- $(\mathrm{OH}) \mathrm{D}$ in the serum was performed using an automatic immunochemiluminescent system IMMULITE 2000. The unit of measurement is nmol / l. At indicators of blood serum below 25- $(\mathrm{OH}) \mathrm{D}$ - obvious deficiency, $50 \mathrm{nmol} / \mathrm{l}$ - deficiency of vitamin D, 50 - $75 \mathrm{nmol} / \mathrm{l}$ - inadequacy of receipt of vitamin D, over $75 \mathrm{nmol} / \mathrm{l}$ - normal supply of vitamin D $[15,16]$. Levels of free fractions of thyroid hormones (f T4, fT3), $\mathrm{TSH}, \mathrm{TSH} \mathrm{Ab}$, ATPO, and 25- $(\mathrm{OH}) \mathrm{D}$ serum were determined in patients before treatment and 3, 6 months after starting therapy with tyrosol and drugs vitamin D. In order to identify possible cellular disorders in the hematopoietic system on the background of tyrosol, a clinical blood test was performed once every 10 days, and in the transition to maintenance doses of the drug once a month.

\section{Statistical Analysis}

Statistical data processing was performed in accordance with the requirements of evidence-based medicine and biostatistics, using the approaches of modern non-infectious epidemiology [17]. The statistical package used the software package SPSS 16.0. and Med Stat. Mann-Whitney criteria were used for odd comparisons [18].

\section{Results}

Its metabolite of vitamin D-25- $(\mathrm{OH}) \mathrm{D}$ is physiologically active in the body. To study the dependence of immune status and thyroid function on sex, age of patients, and the level of 25- $(\mathrm{OH}) \mathrm{D}$, we analyzed the indicators in a combined group of patients - 102 patients before treatment. It was found that among the patients there were 32 men and 111 women, i.e., the number of women with Grave's was 4 times greater than men. The minimum age of patients was 19 years, the maximum - 65. Accordingly, the age categories of $19-30$ years were 21 (14.68\%), $30-49.9$ years-76 (53.15\%), 50 years and older - 46 (32.17\%). Most patients were in the age group of 30-49.9 years. Existing data in the literature indicate the dependence of serum vitamin D content on the age of patients (Table 1).

To study the dependence of immune status and thyroid function on sex, age of patients, and the level of 25- $(\mathrm{OH}) \mathrm{D}$, the analysis of indicators in the combined group of patients with HCG - 102 patients before treatment. It was found that among the patients there were 32 men and 111 women, i.e., the number of women 
with Grave's was 4 times greater than men. The minimum age of patients was 19 years, the maximum -65. No gender differences were found between the indicators. In our study in patients with GD, the highest content of 25- $(\mathrm{OH}) \mathrm{D}$ in serum was observed in the age group 19-30 (Table 2). This group had the lowest titer of antibodies to the TSH receptor. With age, the content of 25- $(\mathrm{OH})$ D in the serum decreased, thus in the age group 30-49.9 years compared with the age group up to 30 years, it was lower by $21 \%$, and in the group aged $>50$ years twice less.

Table 1: Serum 25- $(\mathrm{OH}) \mathrm{D}$ content in Graves' disease and in the control group.

\begin{tabular}{|c|c|c|c|c|}
\hline \multirow{2}{*}{ Total group } & \multicolumn{4}{|c|}{ vitamin D supply criteria $25-(\mathrm{OH}) \mathrm{D}$} \\
\hline & $<25$ & $25-49,9$ & 50-75 & $>75$ \\
\hline \multicolumn{5}{|c|}{ GD } \\
\hline $\mathrm{n}=104$ & $n=21(20,19 \%)$ & $\mathrm{n}=52(50,0 \%)$ & $n=30(28,85 \%)$ & $\mathrm{n}=1(0,96 \%)$ \\
\hline $\begin{array}{c}42,3 \\
{[26,2-52,5]}\end{array}$ & $\begin{array}{c}14,5 \\
{[11,0-18,2]}\end{array}$ & $\begin{array}{c}37,1 \\
{[31,0-45,15]}\end{array}$ & $\begin{array}{c}57,7 \\
{[55,55-67,3]}\end{array}$ & - \\
\hline \multicolumn{5}{|c|}{ Control group } \\
\hline $\mathrm{n}=42$ & $\mathrm{n}=2(4,7 \%)$ & $\mathrm{n}=10(23,8 \%)$ & $\mathrm{n}=26(61,9 \%)$ & $\mathrm{n}=4(9,59 \%)$ \\
\hline $\begin{array}{c}58,85 \\
{[49,07-67,55]}\end{array}$ & - & $\begin{array}{c}43,65 \\
{[41,8-47,1]}\end{array}$ & $\begin{array}{c}59,6 \\
{[58,5-66,5]}\end{array}$ & - \\
\hline $\mathrm{P}<0,001$ & - & $P=0,062$ & $\mathrm{P}=0,03$ & - \\
\hline
\end{tabular}

Note: Data presented as median and 1-3 quartiles in square brackets. Data compared according to Mann-Whitney criteria. P<0,05 considered to be statistically significant.

Table 2: Immunological parameters and thyroid function depending on the age of patients with GD.

\begin{tabular}{|c|c|c|c|c|c|c|}
\hline Age & Up to 30 years & Aged $30-49,9$ years & $\begin{array}{c}\text { Aged } 50 \text { years and } \\
\text { higher }\end{array}$ & p1 & p2 & p3 \\
\hline Indexes & $\mathrm{n}=13(12,5 \%)$ & $\mathrm{n}=51(49,04 \%)$ & $\mathrm{n}=40(38,46 \%)$ & & & \\
\hline 25(OH)D, nmol/L & $\begin{array}{c}59,1 \\
{[45,6-64,5]}\end{array}$ & $\begin{array}{c}47 \\
{[35,65-55,7]}\end{array}$ & $\begin{array}{c}26,1 \\
{[17,43-37,7]}\end{array}$ & 0,011 & 0,000 & 0,000 \\
\hline rTSH Ab, U/L & $\begin{array}{c}6,5 \\
{[4,22-9,26]}\end{array}$ & $\begin{array}{c}17,1 \\
{[10,25-24,85]}\end{array}$ & $\begin{array}{c}21,95 \\
{[11,52-32,4]}\end{array}$ & 0,001 & 0,001 & 0,161 \\
\hline TSH, U/mL & $\begin{array}{c}0,02 \\
{[0,001-0,03]}\end{array}$ & $\begin{array}{c}0,01 \\
{[0,0025-0,04]}\end{array}$ & $\begin{array}{c}0,009 \\
{[0,001-0,04]}\end{array}$ & 0,627 & 0,827 & 0,558 \\
\hline АТРО, U/mL & $\begin{array}{c}400 \\
{[300-588]}\end{array}$ & $\begin{array}{c}400 \\
{[280-600]}\end{array}$ & $\begin{array}{c}373 \\
{[209,5-524,5]}\end{array}$ & 0,815 & 0,671 & 0,403 \\
\hline $\mathrm{fT}_{4}, \mathrm{pmol} / \mathrm{L}$ & $\begin{array}{c}26,7 \\
{[25,76-28,9]}\end{array}$ & $\begin{array}{c}28,9 \\
{[26,11-36,15]}\end{array}$ & $\begin{array}{c}31,305 \\
{[27,68-39,74]}\end{array}$ & 0,115 & 0,004 & 0,120 \\
\hline $\mathrm{fT}_{3^{\prime}} \mathrm{pmol} / \mathrm{L}$ & $\begin{array}{c}8,8 \\
{[7,2-10,3]}\end{array}$ & $\begin{array}{c}11,9 \\
{[10,22-16,3]}\end{array}$ & $\begin{array}{c}12 \\
{[9,88-18,75]}\end{array}$ & 0,002 & 0,004 & 0,930 \\
\hline Thyroid volume, $\mathrm{cm}^{3}$ & $\begin{array}{c}27,51 \\
{[24,12-46,18]}\end{array}$ & $\begin{array}{c}38,96 \\
{[28,85-55,64]}\end{array}$ & $\begin{array}{c}49,315 \\
{[28,93-74,29]}\end{array}$ & 0,048 & 0,003 & 0,127 \\
\hline
\end{tabular}

Note: Data presented as median and 1-3 quartiles in square brackets. p1 - 30-49.9 compared to group up to 30 years; $p 2$-50 years and older compared to group up to 30 years; $\mathrm{p} 3-30-49.9$ years compared to group 50 years and older. $\mathrm{P}<0,05$ considered to be statistically significant according to Mann-Whitney criteria.

Accordingly, there was an inverse situation of the level of TSH $\mathrm{Ab}$ in serum depending on age. In the age group of 50 years and older, the content of TSH Ab was 3 times higher than in group up to 30 years. Among other indicators, was a significantly increased thyroid volume in the group aged 30-49.9 years and aged 50 years and older group compared to the indicator in the group up to 30 years. In connection with these data, it was important to investigate other indicators depending on the level of vitamin supply. Existing supply criteria for Central Europe distinguish levels: significant insufficiency <25 nmol / l, obvious insufficiency -25-50 nmol / l, moderate insufficiency $50-75 \mathrm{nmol} / \mathrm{l}$, satisfactory supply of more than $75 \mathrm{nmol} /$ l vitamin D $[18,19]$. These data indicate that almost 
all patients with GD are deficient in vitamin D. Due to the small number of cases, the level of satisfactory provision is not included in the table for analysis. When analyzing the data, there were differences only in the level of TSH Ab in the 2nd and 3rd groups compared to the first.

In the group of patients with GD, depending on the level of vitamin D supply, we observed a significant decrease in the level of TSH Ab in only the group 50-75 $25(\mathrm{OH}) \mathrm{D}, \mathrm{nmol} / \mathrm{L}$ compared to the group up to $2525(\mathrm{OH}) \mathrm{D}$, nmol / L (Table 3). This result indicates that only an adequate supply of vitamin D can reduce thyroid damage by antibodies to the TSH receptor. In this regard, it was important to check the effect of treatment with tyrosol combined with vitamin D. An important positive effect on the indicators of thyroid function has treatment with tyrosol, the results of this action are known well. To determine the additional effect of vitamin D, the effects of tyrosol treatment were compared with treatment tyrosol + vitamin D after 3 and 6 months of treatment (Table 4).

Table 3: Immunological parameters and thyroid function depending on the supplement of vitamin $D$ in patients with GD.

\begin{tabular}{|c|c|c|c|c|c|c|}
\hline Indexes & $\begin{array}{c}\text { Up to } 25 \\
\mathrm{n}=21(20,19 \%)\end{array}$ & $\begin{array}{c}25-49,9 \\
n=52(50 \%)\end{array}$ & $\begin{array}{c}50-75 \\
n=30(28,85 \%)\end{array}$ & p1 & p2 & p3 \\
\hline $25(\mathrm{OH}) \mathrm{D}, \mathrm{nmol} / \mathrm{L}$ & $\begin{array}{c}14,5 \\
{[11-18,2]}\end{array}$ & $\begin{array}{c}37,1 \\
{[31,525-45,15]}\end{array}$ & $\begin{array}{c}57,7 \\
{[55,55-63,7]} \\
\end{array}$ & 0,000 & 0,000 & 0,000 \\
\hline rTSH Ab, U/L & $\begin{array}{c}23,6 \\
{[13,1-37,4]} \\
\end{array}$ & $\begin{array}{c}17,15 \\
{[10,53-28,06]}\end{array}$ & $\begin{array}{c}11,85 \\
{[6,28-19,78]} \\
\end{array}$ & 0,145 & 0,010 & 0,081 \\
\hline $\mathrm{TSH}, \mathrm{U} / \mathrm{mL}$ & $\begin{array}{c}0,008 \\
{[0,002-0,05]}\end{array}$ & $\begin{array}{c}0,009 \\
{[0,001-0,03]}\end{array}$ & $\begin{array}{c}0,02 \\
{[0,005-0,04]}\end{array}$ & 0,718 & 0,708 & 0,321 \\
\hline ATPO, U/mL & $\begin{array}{c}400 \\
{[238,9-671]}\end{array}$ & $\begin{array}{c}378 \\
{[201,5-510,25]}\end{array}$ & $\begin{array}{c}427,5 \\
{[303-595,5]}\end{array}$ & 0,850 & 0,546 & 0,205 \\
\hline $\mathrm{fT}_{4}, \mathrm{pmol} / \mathrm{L}$ & $\begin{array}{c}29 \\
{[27-34,4]}\end{array}$ & $\begin{array}{c}30,13 \\
{[27,21-38]}\end{array}$ & $\begin{array}{c}27,9 \\
{[25,82-34,52]}\end{array}$ & 0,435 & 0,394 & 0,087 \\
\hline $\mathrm{fT}_{3}, \mathrm{pmol} / \mathrm{L}$ & $\begin{array}{c}11,6 \\
{[10,36-19]}\end{array}$ & $\begin{array}{c}12,15 \\
{[9,92-17,92]}\end{array}$ & $\begin{array}{c}11,25 \\
{[9,15-15,46]}\end{array}$ & 0,855 & 0,275 & 0,202 \\
\hline Thyroid volume, $\mathrm{cm}^{3}$ & $\begin{array}{c}46,18 \\
{[28,12-82,43]}\end{array}$ & $\begin{array}{c}41,9 \\
{[27,32-56,06]}\end{array}$ & $\begin{array}{c}33,635 \\
{[28,83-51,13]}\end{array}$ & 0,605 & 0,358 & 0,564 \\
\hline
\end{tabular}

Note: Data presented as median and 1-3 quartiles in square brackets. p1 - up to $25 \mathrm{nmol} / /$ compared to 25-49.9; p2 - up to 25 compared to 50-75; p3 - 25-49.9 compared to 50-75 nmol / I. P<0,05 considered to be statistically significant according to Mann-Whitney criteria.

Table 4: Comparison of groups of patients on therapy with tyrosol (group 1) and tyrosol + vit D (group 2) after 3 and 6 months from the start of treatment.

\begin{tabular}{|c|c|c|c|c|c|c|}
\hline \multirow{2}{*}{ Indexes } & \multicolumn{2}{|c|}{3 months of treatment } & \multicolumn{2}{|c|}{6 months of treatment } & \multirow{2}{*}{ P1 } & \multirow{2}{*}{$\mathbf{P 2}$} \\
\hline & $\begin{array}{c}\text { group } 1 \\
\text { ME [Q1 - Q3] }\end{array}$ & $\begin{array}{c}\text { group } 2 \\
\text { ME [Q1 - Q3] }\end{array}$ & $\begin{array}{c}\text { group } 1 \\
\text { ME [Q1 - Q3] }\end{array}$ & $\begin{array}{c}\text { group } 2 \\
\text { ME [Q1 - Q3] }\end{array}$ & & \\
\hline $25(\mathrm{OH}) \mathrm{D}, \mathrm{nmol} / \mathrm{L}$ & $\begin{array}{c}46,05 \\
{[33,07-54,13]}\end{array}$ & $\begin{array}{c}49,75 \\
{[39,7-64,73]}\end{array}$ & $\begin{array}{c}46785 \\
{[36,15-55,15]}\end{array}$ & $\begin{array}{c}69,8 \\
{[59,5-76,2]}\end{array}$ & 0,011 & 0,021 \\
\hline rTSH Ab, U/L & $\begin{array}{c}8,4 \\
{[4,05-11,53]}\end{array}$ & $\begin{array}{c}4,49 \\
{[1,52-9,25]}\end{array}$ & $\begin{array}{c}2005 \\
{[0,78-3,2]}\end{array}$ & $\begin{array}{c}1,19 \\
{[0,57-2,08]}\end{array}$ & 0,000 & 0,000 \\
\hline TSH, U/mL & $\begin{array}{c}0,375 \\
{[0,19-0,91]}\end{array}$ & $\begin{array}{c}1335 \\
{[0,93-2,23]}\end{array}$ & $\begin{array}{c}1,18 \\
{[0,9775-1,75]}\end{array}$ & $\begin{array}{c}1,99 \\
{[1,45-2,61]}\end{array}$ & 0,124 & 0,010 \\
\hline ATPO, $\mathrm{U} / \mathrm{mL}$ & $\begin{array}{c}347 \\
{[257,75-600]}\end{array}$ & $\begin{array}{c}310,5 \\
{[180-520]}\end{array}$ & $\begin{array}{c}400 \\
{[300-600]}\end{array}$ & $\begin{array}{c}294 \\
{[167,75-500]}\end{array}$ & 0,112 & 0,066 \\
\hline $\mathrm{fT}_{4}, \mathrm{pmol} / \mathrm{L}$ & $\begin{array}{c}15,945 \\
{[12,35-18,28]}\end{array}$ & $\begin{array}{c}13,79 \\
{[12,21-16,05]}\end{array}$ & $\begin{array}{c}14,06 \\
{[12,425-15,6]}\end{array}$ & $\begin{array}{c}15,15 \\
{[13,43-16,4]}\end{array}$ & 0,061 & 0,310 \\
\hline $\mathrm{fT}_{3}, \mathrm{pmol} / \mathrm{L}$ & $\begin{array}{c}3,815 \\
{[2,86-4,46]}\end{array}$ & $\begin{array}{c}3,185 \\
{[2,86-4,05]}\end{array}$ & $\begin{array}{c}3,105 \\
{[2,68-3,54]}\end{array}$ & $\begin{array}{c}3,12 \\
{[2,87-3,76]}\end{array}$ & 0,14 & 0,047 \\
\hline Thyroid volume, $\mathrm{cm}^{3}$ & $\begin{array}{c}41,635 \\
{[25,89-54,18]}\end{array}$ & $\begin{array}{c}29,855 \\
{[22,18-44,57]}\end{array}$ & $\begin{array}{c}41,56 \\
{[26,33-55,39]}\end{array}$ & $\begin{array}{c}29,11 \\
{[20,36-42,58]}\end{array}$ & 0,025 & 0,000 \\
\hline
\end{tabular}

Note: Data presented as median and 1-3 quartiles in square brackets. P1 - compared to group 1 after 3 months of treatment; P2 - compared to group 1 after 6 months of treatment according to the Mann-Whitney test. $P<0,05$ considered to be statistically significant. 
Due to the appointment of vitamin D in the second group compared to the first level of $25(\mathrm{OH}) \mathrm{D}$ was significantly higher after 3 and 6 months of treatment. Vitamin D treatment had a positive effect on the normalization of serum TSH Ab levels. After 3 months of treatment, the level of TSH Ab in the serum during treatment with vitamin D supplementation was twice lower than when treated with tyrosol alone. After 6 months, compared with treatment with tyrosol, the effect of treatment was 2 times better. It is impossible not to note another positive effect of vitamin D. Compared to tyrosol treatment alone, there was a significant increase in TSH levels and a decrease in thyroid volume after 6 months.

\section{Discussion}

Vitamin supply was investigated for serum $25(\mathrm{OH})$ D levels. After the passage of this metabolite through the kidneys, an even more active compound 1,25 dihydroxy vitamin D is formed. Data on this compound in various diseases, including endocrine diseases, are limited. The short half-life of 1.25 dihydroxy vitamin D, about 4 hours, and its low pmol / L concentrations pose significant technical obstacles to the determination of the compound. At the same time, the excretion of 1,25-dihydroxyvitamin $\mathrm{D}$ from the kidneys into the blood is proportional to the entry of $25(\mathrm{OH}) \mathrm{D}$ into the kidneys. The enzymes of the vitamin D system have been found to change their function depending on the 25-hydroxyvitamin D level in the blood; the definition of the latter is classified as the kinetics of the vitamin D system of the first order reaction [19]. An important source of vitamin D in the body is its synthesis in the skin. In our study, the $25(\mathrm{OH}) \mathrm{D}$ content was the highest in young patients who lead an active lifestyle and spend more time outdoors. Serum 25 (OH) D decreased with age, while an inverse relationship was observed between TSH Ab levels when this parameter increased.

When analyzing the level of antibodies to TSH by the level of vitamin D intake, reliable values of antibodies to TSH were obtained only at levels from $25(\mathrm{OH}) \mathrm{D}$ to $50-75 \mathrm{nmol} / \mathrm{L}$. Thyroid function indicators within these limits did not change. These data are consistent with a recent publication by Indian authors [11] indicating the importance of vitamin D in the regulation of immune status in GD. An important treatment for GD is the use of antithyroid drugs, including tyrosol. Because of the effect of vitamin D on immune status and the importance of this component in the development of GD, the effect of a vitamin in addition to tyrosol on thyroid function has been studied. These parameters were studied in patients who received tyrosol and who received tyrosol with vitamin D. In some cases, with a sufficient content of vitamin $\mathrm{D}$, a positive effect on the indicators of thyroid function was obtained. we believe that this issue requires further study with a larger sample of Grave's patients.

\section{Conclusion}

Data on low vitamin D supply were obtained both among the control group and Graves' patients. At the same time, the provision of vitamin D in Graves' patients was significantly lower than in the control group. A decrease in the level of vitamin D in the blood with age was found. An inverse relationship was found between the content of antibodies to the TSH receptor in comparison with the content of vitamin D. Treatment of Graves' patients with tyrosol combined with vitamin D improves the parameters of the immune status and thyroid function.

\section{References}

1. Prietl B, Treiber G, Pieber TR, Amrein K (2013) Vitamin D and immune function. Nutrients 5: 2502-2521.

2. Charoenngam N, Shirvani A, Holick MF (2019) Vitamin D for skeletal and non-skeletal health: What we should know. J Clin Orthop Trauma 10(6): 1082-1093.

3. Wang TJ, Zhang F, Richards JB, Kestenbaum B, van Meurs JB, et al. (2010) Common genetic determinants of vitamin D insufficiency: a genome-wide association study. Lancet 376(9736): 180-188.

4. Bouillon R (2017) Genetic and racial differences in the vitamin D endocrine system. Endocrinology Metabolism Clinics 46(4): 11191135.

5. Dankers W, Colin EM, van Hamburg JP, Lubberts E (2017) Vitamin D in autoimmunity: molecular mechanisms and therapeutic potential. Front Immunol 7:697.

6. Charoenngam N, Holick MF (2020) Immunologic Effects of Vitamin D on Human Health and Disease. Nutrients 12(7): 2097.

7. Zakharchenko TF, Kravchenko VI (2020) Features of innate and adaptive immunity in the pathogenesis of autoimmune diseases of the thyroid gland. ways of immune correction, immunotherapy. International Journal of Endocrinology 16: 7.

8. Simsek Y, Cakır I, Yetmis M, Dizdar OS, Baspinar O, et al. (2016) Effects of Vitamin D treatment on thyroid auto immunity. J Res Med Sci 21: 85.

9. Alhuzaim 0, Aljohani N (2014) Effect of Vitamin D3 on Untreated Graves' Disease with Vitamin D Deficiency. Clin Med Insights Case Rep 7: 83-85.

10. Yasuda T, Yasuyuki O, Noboru H, Kazuyuki M, Mitsuyoshi T, et al. (2012) Serum vitamin D levels are decreased and associated with thyroid volume in female patients with newly onset Graves' disease. Endocrine 42(3): 739-741.

11. Mangaraj S, Choudhury AK, Swain BM, Sarangi PK, Mohanty BK, et al. (2019) Evaluation of Vitamin D Status and its Impact on Thyroid Related Parameters in New Onset Graves' Disease- A Cross-sectional Observational Study. Indian J Endocrinol Metab 23(1): 35-39.

12. Xu M, Cao B, Yin J, Wang DF, Chen KL, et al. (2015) Vitamin D and Graves' Disease: A Meta-Analysis Update. Nutrients 7(5): 3813-3827.

13. Brunn J, Block U, Ruf G, Bos I, Kunze WP, et al. (1981) Volumetric analysis of thyroid lobes by real-time ultrasound (author's transl). Dtsch Med Wochenschr 106(41): 1338-1340.

14. Sackett DL, Rosenberg WM, Gray JA, Haynes RB, Richardson WS (1996) Evidence based medicine: what it is and what it isn't. BMJ 312(7023): 71-72.

15. Pludowski P, Karczmarewicz E, Bayer M, Carter G, Chlebna-Sokol D, et al. (2013) Practical guidelines for the supplementation of vitamin D and the treatment of deficits in Central Europe - recommended vitamin D intakes in the general population and groups at risk of vitamin D deficiency. Endokrynol Pol 64(4): 319-327.

16. Pludowski P, Grant WB, Bhattoa HP, Bayer M, Povoroznyuk V, et al. (2014) Vitamin D status in Central Europe. International Journal of Endocrinology 2014: 589587. 
17. Beaglehol R, Bonita R, Kjelstrom T (1994) Fundamentals of epidemiology. Geneva 259.

18. Armitage P, Berry G, Matthews JNS (2001) Statistical Methods in Medical Research. 4th Edition, Wiley-Blackwell, Pp. 832.
19. Umar M, Sastry KS, Chouchane AI (2018) Role of Vitamin D Beyond the Skeletal Function: A Review of the Molecular and Clinical Studies. Int J Mol Sci 19(6): 1618.

Your next submission with Juniper Publishers will reach you the below assets

- Quality Editorial service

- Swift Peer Review

- Reprints availability

- E-prints Service

- Manuscript Podcast for convenient understanding

- Global attainment for your research

- Manuscript accessibility in different formats ( Pdf, E-pub, Full Text, Audio)

- Unceasing customer service

Track the below URL for one-step submission https://juniperpublishers.com/online-submission.php 